\title{
THE USE OF MEDIA TEXTS IN RUSSIAN LANGUAGE TEACHING
}

\author{
Andrea Spisiakova \\ University of Ss. Cyril and Methodius (Trnava, Slovakia) \\ ORCID ID: https://orcid.org/0000-0001-7041-1436 \\ Olga Iermachkova \\ University of Ss. Cyril and Methodius (Trnava, Slovakia) \\ ORCID ID: https://orcid.org/0000-0002-5430-7898 \\ Lukas Gajarsky \\ University of Ss. Cyril and Methodius (Trnava, Slovakia) \\ ORCID ID: https://orcid.org/0000-0001-8090-6977
}

\begin{abstract}
At present, we observe active development of new methods and strategies of teaching foreign languages, in which mass media materials play an important role because they provide authentic resources that offer natural language environment and enrich the curriculum and syllabus. These resources can be easily adapted to suit different levels of language proficiency, interests and needs of the students. The study attempts to substantiate the necessity and importance of using various types of authentic media materials in the classroom and analyzes the challenges teachers may face in the process of teaching. The aim of the study is to address both the theoretical background and the practical issues of application of media texts at the lessons of Russian as a foreign language. They enhance not only language but and socio-cultural proficiency of the students and their understanding of linguistic phenomena such as various stylistic figures of speech, phraseological units, linguistic means of manipulation, etc. Mass media resources can be used to develop media literacy, critical thinking and analytical skills. This study is based on the use of general scientific methods such as analysis, description and interpretation. The authors fall back on scholarly literature and their personal experience of teaching Russian. The article suggests using practical media-based approaches to develop language skills and psychological properties, such as memory, prediction skills, and speed of response to linguistic stimuli in undergraduate university students of Russian as a second language. The opportunities and methods regarded in the study can be used in any other classroom of Russian as a second language.
\end{abstract}

Keywords: Russian as a foreign language; methods of teaching Russian; media texts; media discourse; mass media; journalism; learning material; exercises.

\section{ИСПОЛЬЗОВАНИЕ МЕДИЙНЫХ ТЕКСТОВ В ОБУЧЕНИИ РУССКОМУ ЯЗЫКУ}

\section{Спишьякова А.}

Университет св. Кирилла и Мефодия (Трнава, Словакия)

ORCID ID: https://orcid.org/0000-0001-7041-1436

Ермачкова О.

Университет св. Кирилла и Мефодия (Трнава, Словакия)

ORCID ID: https://orcid.org/0000-0002-5430-7898

\section{Гаярски Л.}

Университет св. Кирилла и Мефодия (Трнава, Словакия)

ORCID ID: https://orcid.org/0000-0001-8090-6977 
Аннотация. В наше время наблюдается активная разработка новых методологий и стратегий обучения иностранным языкам, в которой материалы СМИ занимают почетное место, представляя собой аутентичные ресурсы, транслирующие естественную языковую среду и обогащающие учебный план. Эти источники можно легко адаптировать к разным уровням владения иностранным языком, интересам и потребностям учащихся. В данном исследовании авторы стремятся указать на необходимость и значимость применения различных типов медийных материалов в аудитории, а также анализируют проблемы, с которыми сталкиваются преподаватели в процессе обучения. Цель исследования - рассмотреть как теоретические основы, так и практические вопросы использования медийных текстов на занятиях по русскому языку как иностранному. Тексты СМИ повышают не только языковые, но и социально-культурные знания учащихся, углубляют понимание языковых явлений, таких как различные стилистические фигуры речи, фразеологические единицы, приемы языкового манипулирования и т. д. Материалы СМИ могут использоваться для развития медиаграмотности, критического мышления и аналитических навыков. Данное исследование базируется на общенаучных методах, таких как анализ, описание и интерпретация. В работе авторы опираются на научную литературу, а также используют свой личный опыт. В статье предлагаются практические подходы с применением медийных материалов, способствующие развитию навыков владения языком и психологических качеств, таких как память, прогнозирование, быстрота реакции на языковые стимулы у студентов бакалавриата, которые изучают русский язык как иностранный. Возможности и методы, рассматриваемые в данном исследовании, могут быть использованы в любой аудитории, изучающей русский язык.

Ключев ы е слова: русский язык как иностранный; методика преподавания русского языка; медиатексты; медиадискурс; средства массовой информации; журналистика; СМИ; учебный материал; упражнения.

Для иитирования: Спишьякова, А. Использование медийных текстов в обучении русскому языку / А. Спишьякова, О. Ермачкова, Л. Гаярски. - Текст : непосредственный // Филологический класс. - 2021. - Т. 26, № 2. - С. 245-253. - DOI: 10.51762/1FK-2021-26-02-21.

\section{Introduction}

Learning foreign languages is of inexpressible value in today's globalised society. Therefore, naturally, teachers seek effective methods and materials to prepare their students adequately for the modern communication in our ever-changing world. The traditional teaching of grammar, reading of "ready-made" dialogues, various types of drill and translation exercises have been proven effective in teaching of beginner and pre-intermediate levels of Russian language. However, the higher the level of students' skills is, the more it is necessary to supplement textbook materials and enrich the prescribed syllabus with authentic and culturally-saturated texts.

In recent years, we have perceived an active development in teaching of foreign languages. This is also manifested in a shift from artificially created language environment to an effort to establish a natural language environment as much as possible. This not only stimulates students' interest, but also increases their language proficiency, which eventually is much needed for students' academic success and their future careers.
For citation: Spisiakova, A., Iermachkova, O., Gajarsky, L. (2021). The Use of Media Texts in Russian Language Teaching. In Philological Class. Vol. 26. No. 2, pp. 245-253. DOI: 10.51762/1FK-2021-26-02-21.

\section{Research methods}

The presented study aims to research the utilizing mass media texts for teaching Russian as a second language as one of effective means to support natural language environment. The objectives of the study are to address both theoretical background and practical questions of incorporating these texts in the lecture rooms and classrooms. Mass media text will be understood broadly as a spoken or written product of different mass media types and formats.

This study is based on the use of general scientific methods, such as analysis, comparison, description and interpretation. These methods are used for theoretical interpretation of articles, monographs and textbooks on foreign language teaching and different methodologies of incorporation of mass media texts. The study also follows personal teaching experience of authors and intensive study of relevant scientific literature.

\section{Literature review}

The importance of incorporation of mass media texts in lessons of undergraduate students or 
in any other foreign language classroom is extensively discussed and researched. The authors focus on various aspects, namely the role and the importance of mass media texts in teaching foreign languages [Tafani 2009], types of approaches to mass media text analysis [Cykunov 2015], practical exercises to practise productive and receptive skills [Duda 1997, Sanderson 2002], practical recommendations of online media resources [Zan'ko 2019], and many others aspects. This study will elaborate practical exercises to improve productive and receptive skills of undergraduate students.

\section{Results and discussion}

Using various types of media texts in the teaching of foreign languages is always a reasonable choice for a number of reasons. First of all, mass media provide the students with authentic "live" language sample of native speakers. "They promote practical imitation of natural language environment" [Timoshenko 2015: 46]. Students acquire new vocabulary and grammatical structures in context, in their natural collocations, which has been proven much more effective than memorising isolated words from vocabulary lists. "The students are in touch with "real" language, which is not purified from non-standard expressions and slang" [Kunovská 2015: 66].

Teachers acknowledge the ability of mass media texts to be "tailor-made" for various levels of students' knowledge. They can be simplified to a point that they are slightly above the students' level, which is in accordance with generally acknowledged foreign language teaching methodologies. In addition, they can be adapted to meet various specific needs and interests of students. It is an exhaustive source for developing reading, writing, speaking and listening skills at the same time, practising already acquired material as well as new vocabulary and grammar acquisition.

The first apparent skill being developed is reading. Not only mass media texts promote reading in the classroom, according to V. Tafani they promote extensive outside classroom reading as well "[...] by giving the students the confidence, the motivation and the ability to continue their reading outside the classroom" [2009: 81]. Mass media cover a wide range of up-to-date material in different formats. Listening can be primary target of our attention as well. Remaining skills - writ- ing and speaking can be incorporated in practice smoothly. Moreover, "systematic studying of newspaper texts helps to develop the methods of independent work that is very important for foreign language learning" [Timoshenko 2015: 46]. Student gains tools to improve his language, social and cultural competence by himself.

The appropriateness of studying mass media texts in a classroom also resides in the fact that mass media are recognized as a "forth power". In this age of information technology and multimedia exposure, teaching students in alignment with the requirements of the $21^{\text {st }}$ century necessarily involves development of media literacy, critical thinking and analytical skills. "Media competence is now automatically added to the list of basic competencies that need to be emphasized" [Kunovská 2015: 64].

Within this scope of media study it is desirable to turn students' attention to media manipulation. A number of researchers consider manipulative influence to be one of the most important functions of modern mass media along with information function. It seems that "[...] the function of influence today supplants all other functions" [Kuzmina 2011: 25]. Therefore, the notion media-literate person necessarily involves "[...] the ability to recognize negative, manipulative elements, reveal racial prejudice and intolerance" [Kunovská 2015: 67]. Students can be introduced to common practices of language manipulation in mass media. A. A. Gavrilov recognizes following means of manipulation: distortion, selection, withholding of information, metaphorization, using of euphemisms and dysphemisms [2012: 49-52] and many others. Recognition of these means as a way to influence recipient's mind and behavior can be part of overall text analysis. The metaphors, phraseological units, word play, intertextuality and other means need to be perceived not just stylistic means but as a very powerful tool.

The last but not least, mass media resources are an ideal material to study the changes the language undergoes. It is useful for advanced students to keep up with these changes and to comprehend them. On one hand, mass media mirror the changes precisely. On the other hand, researchers acknowledge mass media contribute extensively to formation of new norms of Russian language [Vološina 2016; Valgina 2001]. 
Russian in this respect is a very dynamic language. It is particularly rich for active tendencies, borrowings and the use of slang. Foreign language students can find Russian in mass media emotional, expressive, full of word play, and allusions to Russian history and literature. This makes it considerably difficult for a non-native student to read original mass media texts without a proper preparation. Nonetheless, this fact should not discourage teachers and students to study mass media texts, as this will promote their true understanding of the mentality of the nation and its culture.

The advantages of mass media text incorporation in classrooms presented above are not perceived only from the point of view of the teachers. The students generally positively evaluate this method of learning. The survey about the efficacy of mass media in English language teaching conducted by V. Bhuvaneswari and G. Christopher reveals that all students agreed that the use of mass media for English language teaching breaks the monotony and makes the class more interesting. Further, $96 \%$ of the students agreed that the use of mass media always leads them to a better understanding of the concepts, $88 \%$ of the students agreed to the research statement that their analytical skill is enhanced because of mass media practice. Furthermore, $97 \%$ of the students agreed that the usage of mass media materials fosters creative thinking [2020: 597-598]. The results stated in this survey undoubtedly prove that mass media texts in any language learning have much to offer to students if used correctly and efficiently.

With advantages been clearly stated and defined the question of limitations arises and we cannot evade reflecting this aspect as well. The challenges of mass media material in the classrooms are described by V. Bhuvaneswari and G. Christopher as follows: 1. Facilities like Smart Board, LCD projector, internet connectivity, the sound system may not available in all the classrooms. 2. Teachers should be proficient in handling technology properly. 3 . There is a possibility that students turn into passive observers than active participants in the classroom. 4. Planning and preparation takes time [2020:598]. From our point of view we regard one more aspect as a limitation. Not only the planning and preparation of such a lesson is time consuming, it requires a sig- nificant amount of teacher's creativity. The teacher needs to be knowledgeable in all disciplines of linguistics and know the culture well. Still, the positive aspects prevail over negative ones.

To prepare effective lessons with mass media materials it is desirable to meet some basic requirements for their selection. I. V. Cykunov describes selection criteria as follows: sufficient volume, not too long for comprehension and not too short to allow in-depth interpretation; bright linguistic characteristics that allow to explore the modality of the text in its various manifestations; significant authorship of interest from a linguistic and cultural point of view (famous writers, poets, directors, politicians and public figures); cultural and historical significance. The main thing is that the media text is a detailed statement with all the characteristics of a full-fledged text (structure and completeness) [2015:38].

Let us now proceed to practical methods of utilizing mass media resources in the classroom. Any practice should always include short introductory phase to introduce the topic or mass media text type and to excite students' interest. It can include variety of activities like queries about students' background knowledge about the topic, predicting the storyline based on the headline / picture / photo / keywords, brainstorming, small discussion and other methods. These activities can promote students' interaction among themselves.

We can be sure that there will be new vocabulary and grammar structures for our students in authentic mass media materials. The decision to pre-teach vocabulary is in teacher's hands. However, there are a few points to consider in this regard. First of all, students do not need to know each and every word in the text. This would eventually support a formation of a "mental block" in students. They need to develop a certain tolerance for unknown vocabulary if they are expected to continue working with authentic Russian resources outside the classroom. Moreover, useful skills are being developed if we skip pre-teaching like deducing meaning of words from the context and general understand of the text. Therefore, pre-teaching should be meaningful and should include only vocabulary that is absolutely crucial for understanding the main idea of a text. The pre-teaching itself can be in the form of guessing the meaning and giving definitions. Stu- 
dies show $98 \%$ lexical coverage provides adequate comprehension of a written text; the remaining $2 \%$ can be guessed from context easily [Nation 2009: 6].

Let us now consider what options mass media texts offer to teachers for practicing and improving productive and receptive skills of the students. Mass media texts provide various activities to practise speaking. The warm-up of a lesson can be an open discussion about what interesting news students have read or listened to during the past week. This is an excellent way to start a lesson. Not only it provides students with speaking time, it also reflects their interests, which can be utilised by teacher in process of selecting mass media material. To promote speaking skills even more students can be asked to retell the story/ summarize the article/audio, to describe visual components (pictures, photos), to predict stories by looking at photographs/headlines, to ask questions, exchange the news, act out, to moderate the discussion. Students can be encouraged to solve problems covered in the text. This activity can be accompanied by a search quest - students find out more about the topic and present information found afterwards.

D. Duda suggests to go beyond the text and to expand the news story by role-playing interviews with students who pretend to be characters from the news or "eyewitnesses" [Duda, 1997: 21]. This activity is effective speaking practice and makes the article more realistic for the students.

Advertisement contest: students select and critically analyse advertisements they consider offensive, inappropriate, good or funny.

Deeper understanding of advertisements can be achieved by a following activity: Teacher distributes advertisements cut from newspapers. Students try to determine the advertising techniques used in particular advertisements and their efficiency. Teacher moderates the discussion and elicits the persuasive and psychological techniques affecting buying decisions like playing on human's fears, sexual attractiveness, peer pressure, nostalgia, famous people, faith and hope [Baryshnikova, 2017: 16-28] and many others.

The second skill to be considered is reading. Mass media resources provide an extensive database for practising this receptive skill. Reading mass media texts can be utilized to develop several competences: reading comprehension, vocabulary and grammar practice. Students can train different reading techniques: skimming reading for gist, scanning - reading for specific information. Scavenger hunt activity combines all these techniques. Teacher compiles a list of points students will be given to find in a certain newspaper or magazine. Students then work together or individually to find the items, such as an article about politics, a birth announcement, a story about courage, an ad for a cell phone, find a picture of an important world leader, a piece of advice, etc. "The scavenger hunts not only familiarize students with the terminology of the newspaper and give them practice with skimming and scanning, but they also familiarize the students with the layout of a newspaper" [Duda 1997: 21].

Except the simple reading of the text, it is advised to support it by activities, ideally pre-reading, while-reading and post-reading activities that can be made up from following but also other tasks: rearranging jumbled up paragraphs, true/false statements, multiple-choice questions, filling in the blanks; instead of questions, students can be asked to carry out tasks such as: circle, underline, describe, explain, research, create a better headline etc.

Guess the headline activity: headlines are cut out from different news, mixed and distributed to students together with articles. Students read the news and match them with the corresponding headlines.

Following activity suggestions are focused on writing as a productive skill. Mass media text can be used to enhance writing in various ways. Students can practice simple making notes while reading/listening, writing weather reports, advertisements, advice columns, and classified ads. Activity Write a letter to the editor: students read or listen to the mass media text and then write a letter to the editor expressing their opinions, concerns, or complaints.

Creative writing: a report for an imaginary newspaper: students are assigned the type of newspaper: broadsheet or tabloid. Two sets of cards are distributed among the teams of students: prompts with name of a well-known person: e.g. actors, singers, president, etc., and scenario e.g.: love affair, scandal, strike, holiday, drugs etc. Students write their own fictional story about the person and scenario prompts given. One member of a team presents story. The students can vote which 
story they liked the most. Points will be awarded for originality, vocabulary, spelling, grammar, headlines, and additional visual components.

Write the last paragraph activity combines reading with writing output. Students practise skill to sum up and wrap up already read information. At the end of the activity, teacher can read the original last paragraph for comparison.

Silent Movie activity: students watch a small segment of the film, preferably a dialogue, without sound. Their task is to write a script for the movie in pairs or in groups. Then they present their work. The original is played at the end for comparison.

Distribute headlines among groups of students and ask them to choose one and write a news story that would go with it. Once their stories are completed, provide the students with the original stories. Discussion is stirred up about how close they were to the original and to what extent the headline conveyed the meaning.

Students should be given opportunities to read and to respond to one another's writing. The method of peer review can be an effective and useful tool to collaborate, to learn how to formulate constructive feedback and to improve their own writing. Peer review together with teacher's final evaluation can provide the author with valuable feedback and stimuli.

Knowledge about mass media text types also needs to be trained and developed. Students are able to be differentiate between news, comment and analysis, feature and advertisement after short discussion and practice. These texts manifest a different level of relationship between informing and persuading. "By comparing news articles to editorials, feature stories, and advertisements, students can better see the differences between fact and opinion" [Duda 1997: 21]. This can help students to become responsible and aware recipients.

D. Duda suggests a following exercise to prompt students to evaluate text types: students compare a news article and a comment and analysis or feature story. They circle all judgmental statements or words, including all adjectives and adverbs and compare their frequency in the different kinds of writing. Students can then see what the author is trying to accomplish. This provides a perfect opportunity to discuss purpose, style, and audience [1997: 21].
If we want students to actively produce different types of these texts on their own, they should also be informed about the text characteristics (terms such as hard news, soft news, 5 W's, inverted pyramid are introduced in the case of news). One activity to promote students' deeper understanding of different kinds of texts is active production, which can be conducted in several ways. Teacher can ask students to rewrite an original piece of news to feature or comment and analysis or vice versa. The second option is to assign a common topic to all groups and the text type. Students then work in groups to write about that topic in compliance with the text characteristics requirements they were assigned. The texts are presented and evaluated in the end of the activity.

The last skill to be discussed is listening. Information technologies allow us to use extensive mass media resources as a valuable practice of this receptive skill. Learners can benefit from listening to authentic news and programmes in Russian to a large extent. Such a practice helps them to develop their own listening strategies that will be effective in coping with listening comprehension in every other topic and area of Russian language.

T. Zan'ko suggests following methods to be used after listening: discussion of the main idea of the audio; characteristics of the participants in the audio based on their statements; work with lexical and phraseological units, grammatical structures used; work with the types of intonation structures found in the text; students can express their agreement/disagreement with the opinion of the participants and they can provide the argumentation of their own opinion [Zan'ko 2019: 92]. Diverse activities can encourage the learners to listen to Russian language more outside the classroom.

Authentic mass media materials can be used not only for studying the Russian vocabulary and practicing receptive or productive skills, although they have been proven effective for these purposes. "Most newspapers are linguistically up-todate and provide valuable linguistic data. They may be used for the wide variety of text types and language styles, not often found in textbooks" [Tafani 2009: 84]. Mass media in general play an irreplaceable role in introduction and subsequent practice of linguistic phenomena, whether that 
is slang, terms, dialectisms, literary expressions, journalistic clichés, metaphors and other stylistic expressive language means, phraseological units and their transformations and others. Students should be able to recognize these units in mass media text and to name them. The further practice and discussion aims at promotion of true understanding of a language of mass media and the reason behind choosing each linguistic means by experienced journalists. In this way we can interconnect linguistics with cognitive and linguo-cultural approach.

Such analysis may lead to definition of linguistic tendencies that are reflected in mass media. Students can be trained to see the use of slang, colloquial vocabulary as a manifestation of democratization of Russian language, which follows democratization of Russian society. On the other hand, metaphors, irony, precedent phenomena, word play is perceived as a sign of intellectualization - i.e. an intentional attempt to make the text harder for the recipient. These tendencies result from abolition of censorship in Russia and pressing competition among mass media.

Special attention should be paid to metaphors during linguistic analysis, as metaphors are not just a mere stylistic means: "The metaphor permeates our entire daily lives and manifests itself not only in language but also in thinking and acting. Our everyday conceptual system, which we think and act within, is essentially metaphorical" [Lakoff, Johnson 2004: 25]. By analyzing the text and metaphors in it, we can reach a deeper understanding of the described fact, as well as the purpose for which the article was written. The same is applied to phraseological units and paremias. "It is becoming more and more common in the press to use proverbs and sayings (especially in a transformed updated form) in order to influence perception facts from a certain point of view" [Dulebová 2011: 110].

Mass media texts provide an excellent opportunity to study how stereotypes are formed, how verbal aggression is achieved by linguistic means. The students need to understand that: "an experienced journalist operates with symbols, archetypes and rituals with the mass (public) consciousness of the period and the nation" [Dulebová 2011: 110].

\section{Conclusion}

Our study has shown the importance of incorporating authentic mass media texts in the classroom of Russian as a foreign language but also has suggested some practical exercises and activities to interest students in mass media, to expand their vocabulary and knowledge of grammar and to promote productive as well as receptive skills by means of interactive activities. Teachers are encouraged to use mass media materials at the lessons, despite their difficult language. Certain exercises and tasks have been described that could help to design tasks with regard to various language levels and interests of our students in compliance with the famous maxim in language teaching: Grade the task not the material [Sanderson 2002].

Naturally, the activities and exercises described in this study do not exhaust all the possibilities mass media materials provide in teaching Russian as a second language. Hopefully, they can encourage the teacher to take advantage of mass media resources and help him to approach their incorporation in the lessons creatively.

The activities and exercises suggested in the study improve not only knowledge of Russian language, but also develop four basic language skills and psychological qualities of students, such as memory, prediction skills, and promptness in reacting to linguistic stimuli. Text analysis in pairs and groups has been shown effective to prompt collaborative learning and discussion among learners. A spirit of cooperation rather than competition may be fostered in this way.

Engaging students to work with mass media materials results in deeper connection and understanding of the language and culture the media transmit. Not only students need to be prepared for the $21^{\text {st }}$ century, the teacher also needs to develop skills and media and technological literacy. The teacher needs to show a certain amount of creativity to step back from textbook material and take the time to plan and prepare lessons. The undergraduate students will be given tools and motivation to work with the unlimited information we have access to and to approach information critically and will be more prepared for real language. 


\section{Литература}

Валгина, Н. С. Активные процессы в современном русском языке :учебное пособие / Н. С. Валгина - Москва : Логос, 2001. - 304 c.

Волошина, С. В. Активные процессы в современном русском языке :учеб. пособие / С. В. Волошина - Томск : Издательский Дом Томского государственного университета, 2016. - 184 с.

Гаврилов, А. А. Средства воздействия СМИ на общественное сознание / А. А. Гаврилов // Динамика систем, механизмов и машин. - 2012. - o 4. - С. 49-52.

Занько, Т. Методические аспекты работы с сетевыми СМИ при обучении аудитории студентов на продвинутом уровне / Т. Занько // Вестник. Современный русский язык: Функционирование и проблемы преподавания. $-2019 .-$ No $^{\circ} 3 .-$ С. $87-93$.

Кузькина, Н. А. Современный медиатекст : учебное пособие / Н. А. Кузьмина. - Омск, 2011. - 414 с.

Лакофф, Дж. Метафоры, которыми мы живем / Дж. Лакофф, М. Джонсон - М. : Едиториал URSS, 2004. $256 \mathrm{c}$.

Цыкунов, И. В. Методика изучения и интерпретации медиатекстов в контексте обучения РКИ / И. В. Цыкунов // Язык и текст. - 2015. - № 2. - C. 36-43.

Baryshnikova, E. Persuasive techniques used in marketing and advertising based on psychological factors / E. Baryshnikova. - Saimaa : Saimaa University of Applied Sciences, 2017. - 45 p.

Bhuvaneswari, V. Efficacy of mass media in English language teaching / V. Bhuvaneswari, G. Christopher // Journal of Critical Reviews. - 2020. - P. 596-599.

Duda, D. Newspaper Stories: Creating a Newspaper for a Fictional Community / D. Duda // Language Arts Journal of Michigan. - 1997. - P. 17-23.

Dulebová, I. Pragmatický potenciál prísloví a porekadiel v ruských a slovenských masmédiách / I. Dulebová // Žurnalistika. Médiá. Spoločnost \#1. - Bratislava : Stimul, 2011. - P. 109-120.

Kunovská, I. Médiá a mediálna kompetencia vo výučbe cudzích jazykov / I. Kunovská // Informačno-komunikačné technológie a vyučovanie jazykov. Pro et contra. - Prešov : Filozofická fakulta Prešovskej univerzity v Prešove, 2015. S. $64-70$.

Nation, I. S. P. Teaching ESL/EFL Reading and Writing / I. S. P. Nation. - New York : First Published, 2009. - 184 p.

Sanderson, P. Using Newspapers in the Classroom / P. Sanderson. - Cambridge : CUP, 2002. - 288 p.

Tafani, V. Teaching English through Mass Media / V. Tafani // Acta Didactica Napocensia. - 2009. - Vol. 2. P. 81-96.

Timoshenko, V. I. The use of Mass Media in the English language teaching process / V. I. Timoshenko // Вестник Карагандинского университета. - 2015. - Р. 46-49.

\section{References}

Baryshnikova, E. (2017). Persuasive Techniques Used in Marketing and Advertising Based on Psychological Factors. Saimaa, Saimaa University of Applied Sciences. 45 p.

Bhuvaneswari, V., Christpher, G. (2020). Efficacy of Mass Media in English Language Teaching. In Journal of Critical Reviews, pp. 596-599.

Duda, D. (1997). Newspaper Stories: Creating a Newspaper for a Fictional Community. In Language Arts Journal of Michigan, pp. 17-23.

Dulebová, I. (2011). Pragmatický Potenciál Prísloví a Porekadiel v ruských a Slovenských Masmédiách. In Žurnalistika. Médiá. Spoločnost'\#1. Bratislava, Stimul, pp. 109-120.

Gavrilov, A. A. (2012). Sredstva vozdeistviya SMI na obshchestvennoe soznanie [Means of Influence of Mass Media on Public Awareness]. In Dinamika sistem, mekhanizmovi mashin. No. 4, pp. 49-52.

Kunovská, I. (2015). Médiá a Mediálna Kompetencia vo Výučbe Cudzích Jazykov. In Informačno-komunikačné technológie a vyučovanie jazykov. Pro et contra. Prešov, Filozofická fakulta Prešovskej univerzity v Prešove, pp. 64-70.

Kuz'kina, N. A. (2011). Sovremennyi mediatekst [Contemporary Media Text]. Omsk. 414 p.

Lakoff, Dzh., Jonson, M. (2004). Metafory, kotorymi my zhivem [Metaphors We Live By]. Moscow, Editorial URSS. 256 p.

Nation, I. S. P. (2009). Teaching ESL/EFL Reading and Writing. New York, First Published. 184 p.

Sanderson, P. (2002). Using Newspapers in the Classroom. Cambridge, CUP. 288 p.

Tafani, V. (2009). Teaching English through Mass Media. In Acta Didactica Napocensia. Vol. 2, pp. 81-96.

Timoshenko, V. I. (2015). The Use of Mass Media in the English Language Teaching Process. In Vestnik Karagandinskogo universiteta, pp. 46-49.

Tsykunov, I. V. (2015). Metodika izucheniya i interpretatsii mediatekstov v kontekste obucheniya RKI [Methodology of Learning and Interpretation of Media Texts in Context of Teaching Russian as a Second Language]. In Yazyk i tekst. No. 2, pp. 36-43.

Valgina, N. S. (2001). Aktivnye protsessy v sovremennom russkom yazyke [Active Processes in Contemporary Russian Language]. Moscow, Logos. 304 p.

Voloshina, S. V. (2016). Aktivnye protsessy v sovremennom russkom yazyke [Active Processes in Contemporary Russian Language]. Tomsk, Izdatel'skii Dom Tomskogo gosudarstvennogo universiteta. 184 p.

Zan'ko, T. (2019). Metodicheskie aspekty raboty s setevymi SMI pri obuchenii auditorii studentov na prodvinutom urovne [Methodological Aspects of Working with Network Mass Media While Teaching Classes of Students with Advanced Level]. In Vestnik. Sovremennyi russkii yazyk: Funktsionirovanie i problemy prepodavaniya. No. 33, pp. 87-93. 


\section{Данные об авторах}

Спишьякова Андреа - кандидат филологических наук, старший преподаватель кафедры русистики философского факультета, Университет св. Кирилла и Мефодия (Трнава, Словакия).

Адрес: 91701, Словакия, г. Трнава, пл. Герду, 2.

E-mail: andrea.spisiakova@ucm.sk.

Ермачкова Ольга Евгеньевна - кандидат филологических наук, старший преподаватель кафедры русистики философского факультета, Университет св. Кирилла и Мефодия (Трнава, Словакия).

Адрес: 91701, Словакия, г. Трнава, пл. Герду, 2.

E-mail:olga.iermachkova@ucm.sk.

Гаярски Лукаш - кандидат филологических наук, старший преподаватель кафедры русистики философского факультета, Университет св. Кирилла и Мефодия (Трнава, Словакия).

Адрес: 91701, Словакия, г. Трнава, пл. Герду, 2.

E-mail:lukas.gajarsky@ucm.sk.

\section{Authors' information}

Spisiakova Andrea - Candidate of Philology, Senior Lecturer of Department of Russian studies of Faculty of Arts, University of Ss. Cyril and Methodius (Trnava, Slovakia).

Iermachkova Olga - Candidate of Philology, Senior Lecturer of Department of Russian studies of Faculty of Arts, University of Ss. Cyril and Methodius (Trnava, Slovakia).

Gajarsky Lukas - Candidate of Philology, Senior Lecturer of Department of Russian studies of Faculty of Arts, University of Ss. Cyril and Methodius (Trnava, Slovakia). 